University of East London Institutional Repository: http://roar.uel.ac.uk

This paper is made available online in accordance with publisher policies. Please scroll down to view the document itself. Please refer to the repository record for this item and our policy information available from the repository home page for further information.

To see the final version of this paper please visit the publisher's website. Access to the published version may require a subscription.

Author(s): Doná, Giorgia.

Article title: Children as Research Advisors: Contributions to a 'Methodology Participation' in Researching Children in Difficult Circumstances

Year of publication: 2006

Citation: Doná, G. (2006) 'Children as Research Advisors: Contributions to a 'Methodology Participation' in Researching Children in Difficult Circumstances', International Journal of Migration, Health and Social Care 2 (2) 20-32

Link to published version:

http://pierprofessional.metapress.com/content/vj88q6v1178145h2

DOI: (not stated)

ISSN: 1747-9894

Publisher statement: (not stated)

Information on how to cite items within roar@uel:

http://www.uel.ac.uk/roar/openaccess.htm\#Citing 


\title{
Children as Research Advisors: Contributions to a 'Methodology of Participation' in Researching Children in Difficult Circumstances
}

\author{
Giorgia Doná \\ Refugee Research Centre, University of East London
}

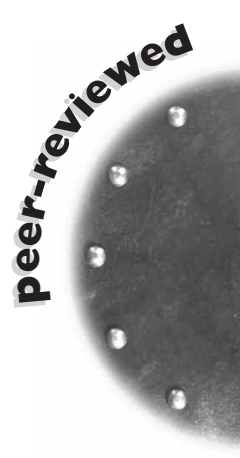

\begin{abstract}
This article contributes to emerging discussions of child participation in general, and in research with migrant and displaced children specifically, by examining the involvement of children as research advisors in two projects: a study of foster care for separated children in Rwanda, and an analysis of the conditions of children outside parental care living in institutions and communities in Bangladesh. The comparison highlights the importance of conceiving participation as a research strategy, and advocates a 'methodology of participation' that considers varieties of participation and varieties of social change. Teaching research methods to children acting as advisors enabled them to understand what research is and to learn about the lives of other children, while contributing to decision-making processes in selecting questions, participants, interpreting findings and making recommendations. Children's input into research contributes to overcoming essentialist conceptualisations of children in difficult circumstances, and moving to viewing these children as social actors embedded in complex relational processes. At the same time, involving children in an advisory capacity treates them as active participants in the research process, as they are in social life.
\end{abstract}

\section{Key words}

child participation; children as co-researchers; children in difficult circumstances; Rwanda; Bangladesh; foster care; children living in institutions

\section{Introduction}

Understanding the lives of children living in difficult circumstances arising from conflict or migration has the potential to inform discussions on childhood in general (Boyden \& de Berry, 2004; Machel 2001) and to influence child-centred programmes and policies (Ackerman et al, 2003). Research is a significant means by which such knowledge is achieved. Research findings contribute to evidence-based policies and act as supporting evidence in funding applications, while information-gathering is relied on in planning, monitoring and evaluating programmes aimed at assisting children in difficult circumstances. Thus, not only researchers, but also nonresearch active practitioners such as social, support and case workers entering into contact with migrant and asylum-seeking children in schools, social care services and community organisations, will benefit from familiarising themselves with the research process as it directly or indirectly affects their work with children.

Since the ratification of the 1989 Convention on the Rights of the Child, there has been increased awareness of the value of child participation in general, and specifically in research, and a consequent interest in the methodological aspects of conducting research with children. These range from specific issues like informed consent and confidentiality (Thomas \& Byford, 2003; Williamson et al, 2005), the role of gatekeepers (Murray, 2005) and the use of child-centred techniques (Barker \& Weller, 2003), to more general areas of concern such as children's understanding of their research rights (Hurley \& Underwood, 2002) or their perspectives on the 
methods used in research (Hill, 2006), issues of power and representation (Christensen, 2004; Grover 2004; Wyness, 2006), ethics of research (Mahon et al, 1996; Morrow \& Richards, 1996) and participatory methodologies (Boyden \& Ennew, 1997; Eyber \& Ager, 2004; Thomas \& O'Kane, 1998).

\section{Evolving conceptualisations of childhood}

Underpinning the idea of child participation in research is a changed conceptualisation of childhood, which until the 1970s was framed within evolutionary discourses of children's biological make-up and confined to motherchild relationships (James, 2004). The explanation (albeit contested) that the existence of a distinct phase in human development, namely childhood, was a recent cultural phenomenon (the French historian Philippe Aries (1962) had argued that childhood had not existed in medieval society) generated a debate that contributed to the emergence of a new paradigm: childhood as a social construction. According to this, children are not objects but social actors, both independent individuals engaged in their social worlds and capable of influencing them, and members of a social category defined by particular social, historical and ideological processes (James, 2004). The dichotomy between children and adults is replaced by the idea of childhood as a social category fundamentally embedded in relational processes, representing interactions among diverse social positions (Mayall, 2002).

This conceptual shift also influenced research with children affected by migration, conflict and poverty, in that their voices and opinions began to be sought. In its simplest form, participation in research means talking to children directly rather than asking their parents or teachers, so that children become subjects rather than objects of research (Christensen \& Prout, 2002). While the change in approach has contributed to more realistic assessments of the lives of many children living in difficult circumstances, they continue to be viewed as independent groups rather than relational categories: street children (Veale \& Doná, 2003), refugee children (Ahearn et al, 2003), and unaccompanied children (Bhabha, 2004; Hek 2005; Thomas \& Byford, 2003), among others. Additionally, explanatory concepts used to describe children in difficult circumstances struggle to overcome the use of dichotomous and often oppositional concepts: vulnerability/resilience, needs/rights, victims/ survivors, traumatised/healthy (Ahearn et al, 2003; Chatty et al, 2005; Summerfield, 2000), essentialising the reality of their identities and lives.

\section{Children as researchers}

To comprehend better the structural, situational and personal complexity of children's lives, researchers rely primarily on the involvement of children as participants, acknowledging the value of their interpretations and accounts. Recently, under aspirations for social inclusion, empowerment and social change, children have begun to be involved not simply as respondents but also in other capacities and at different stages of the research process itself: setting the agenda, choosing topics of investigation, collecting information, interpreting and disseminating findings, and acting upon them (Boyden \& Ennew, 1997; Thomas \& O'Kane, 1998; Kellet, 2005; Kellet et al, 2004). Three accounts of using participation in research with socially excluded young people, namely migrant and refugee children and homeless young people, are presented below to examine the specificities, challenges and value of participation in politically and socially charged environments.

In a study aimed at understanding the worries of Palestinian children living in Gaza from the perspective of the children themselves, MacMullin and Loughry (2000) give an example of children's involvement in the development of research instruments. Children were asked to list and rank the things that worried them most, which constituted the basis for the development of a questionnaire that was distributed to 247 children aged 11 to 16 , and whose findings were discussed in focus group meetings with the children themselves. While previous research on the same topic, but in which concerns were identified from the literature, found that children's worries were family, social relationships and school (Simon \& Ward, 1974), or school work, money and social efficacy (Millar \& Gallagher, 1996), in this study different and unexpected concerns became apparent: corruption, dirty streets, future, death of Iraqi children and car accidents. This is an instance where child participation led to increased awareness about worries on the part of both children and adults. 
Achieving social change was a main objective of Pain and Francis's (2003) participatory research to explore the concerns about crime and experiences of victimisation of socially excluded young people in England. The authors' reflections on the value, challenges and limitations of participatory research offer a useful contribution to emerging discussions on methodological issues specific to participatory research. They examine the use of participatory techniques and procedures, and the social and political factors impinging on meaningful participation. In the context of forced migration, Boyden (2001), too, identified operational, structural and conceptual obstacles to adopting child participation. While participatory techniques are widely viewed as ethically preferable to more conventional methods, Pain and Francis found that they are surrounded with limitations. In their study, while there were many examples of young people feeling victimised, it was not possible to distinguish between perceptions, rumours and personal experiences of crime victimisation. The fact that people moved in and out of group discussions made the sessions dynamic, but lacking in continuity and development. Emergence - participants raising the issues that they want to raise - meant that the goals of the research were not completely met, and analysing the information in a participatory manner raised concerns over the explicit framework of analysis.

The authors also discovered, like others, that despite their ambition to achieve social change, where participants take actions on issues and problems that arise from the research, this is seldom achieved. Barriers to meaningful participation can be practical, conceptual and contextual. Practically, participants, for a full range of reasons continuity in time or different priorities - may choose not to participate in the social change, even when it is clear that it is going to have a positive impact. Conceptually, participation assumes the existence of a 'community', a problematic idea with groups that are transient like the homeless and out-of-school young people in their project. Finally, the socio-political context influences the effectiveness and routes for change; sustainable participatory practices rarely fit well with the structures and cultures of statutory policy-making organisations. In their study, for instance, while young people and social workers identified police attitudes towards homeless and school-excluded people as a significant problem in the city, suggested trainings for the police and even offered to run workshops on understanding young people's situations, their recommendation was met with resistance by the police force. However, in spite of the challenges and limitations, they, like Boyden (2001), concluded that the approach was still valuable for consulting so called 'hard to reach' groups.

A third type of contribution to discussions on participation focuses on its comparative aspects. Chatty and colleagues (2005) used anthropological and participatory methodologies with young Palestinian, Afghan and Sahrawi refugees in exile, and found that participatory methods varied from site to site, that the agendas of the youth groups, the researchers and the local representatives shaped the direction of the research, and that participation does not happen in a social or political vacuum.

In the context of complete self-settlement with no international humanitarian assistance and enrolled in (informal) schools set up by their parents, the Afghan young people were the most outspoken, active and questioning of the refugee groups. From the onset, they adopted the participatory approach and made it their own, reshaping the research strategy; they set up afternoon clubs and various committees including a clean-up committee, a sports committee, a newsletter committee, and a research committee in charge of deciding which individual young people would take part in in-depth interviewing and narratives.The Palestinians, whose lives and education were shaped by UNRWA, were keen to be involved in the project and took the lead in the dissemination of findings. Young Palestinians in Lebanon and Syria prepared booklets identifying research findings to be circulated; in Jordan, funding for a newsletter linking young Palestinians across the country was secured and continued to be produced after the end of the formal project; in the West Bank and Gaza, despite the outbreak of the Second Intifada, several photo and art exhibits took place. Finally, the Sahrawi young people, living under an all-encompassing international humanitarian aid regime organised through the Sahrawi government in exile, were not readily responsive to the participatory goals of the project; they were eager to participate, but viewed participatory exercises as formal extensions of their schoolwork rather than a separate forum for open discussions. 
The authors concluded that divergent research contexts and different experiences and agendas of the young refugees make comparability across the three settings difficult, and raise challenges in the search for methodological commonality, similarities in the data and comparability across field sites. However, their comparisons highlight a communality; participation gives young people agency and ownership and contributes to a greater holistic understanding of young refugees.

Within these emerging methodological reflections on child/youth participation in research, the present examination of the role of children as research advisors aims:

- to examine a specific type of child participation, that of children acting in an advisory capacity

- to describe a technique for participation - teaching basic research methods

- to consider children's empowerment as the acquisition of knowledge and awareness

- to analyse the influence of the context by comparing the involvement of children as advisors in two separate research projects.

I want to bring to attention the importance of thinking methodologically about participation in research by demonstrating that how participation itself is conceived and carried out affects the quality of the process; that, if well-planned, it improves the quality of the overall research project, gives children tools to examine and discuss their lives, and contributes to discussions on children in difficult circumstances that transcend dichotomous explanations.

I will begin with separate descriptions of two research projects in which children participated as advisors: a study of fostering separated children in Rwanda (Doná et al, 2002), and an analysis of the conditions of children outside parental care living in institutions and communities in Bangladesh (Doná \& Islam, 2003). Although these examples are about participation in the research process, lessons can be learnt for planning participatory activities with children in non-research contexts too. Similarly, while the examples illustrated below are about two specific settings, inferences can be drawn for other situations in which children find themselves in difficult environments, for instance children of irregular migrants in countries of asylum, unaccompanied minors settling in alone or trafficked children.

\section{Care arrangements for separated children: the Rwandan experience of fostering}

In the 1990s, Rwandan history was characterised by a:

\author{
crisis of such proportions that every Rwandan \\ is said to have lost touch with at least one \\ member of his or her immediate family \\ (ICRC, 2000 p3).
}

During and after the 1994 genocide, many Rwandan children became internally displaced and refugees, losing family members or being separated from them during violence and flight. Estimates range from 120,266, the number of files of registered unaccompanied Rwandan children in the Great Lakes region gathered by the International Committee of the Red Cross (ICRC, 2000), to the 4-500,000 quoted by the Rwandan government (Minitraso et al, 1996). The immediate response of the government and partner organisations was the identification, documentation, tracing and family reunification of unaccompanied displaced and refugee children inside Rwanda and abroad. By 2000 this initiative had succeeded in re-unifying more than half of the registered unaccompanied minors with a member of the extended family (ICRC, 2000). However, children too young to remember who they were or where they came from at the time of separation, and those for whom tracing had been unsuccessful, remained in centres or in the care of unrelated individuals both inside Rwanda and abroad.

For those unable to return to live with their families, fostering was adopted as the preferred social care option. Fostering is an arrangement in which a child lives with an unrelated family on a temporary basis, without the expectation of permanent membership in the new family, and without any expectation that natural parents will lose their parental rights and responsibilities (Tolfree, $1995 \mathrm{p} 185$ ). In Rwanda, the first instances of 
fostering by an agency were recorded in 1996, and approximately 1,200 unaccompanied children had been fostered by agencies (referred to as 'formal' or 'agency' fostering) by 2000 , in addition to the much larger number of children believed to be spontaneously living with unrelated individuals (referred to as 'spontaneous' or 'informal' fostering).

In 2000, the government, Unicef and Save the Children commissioned a study to document the Rwandan experience of fostering, to examine fostering guidelines and practices for both spontaneous and formal fostering in the legislative context of other types of social care including adoption and guardianship, and to explore the perceptions of fostering by children, foster parents, local authorities and members of local communities. The community-based component of the study involved 415 participants in individual interviews, focus group discussions and group activities - 228 children (55\%) and 187 adults (45\%). A team of five researchers developed the research strategy and instruments, and carried out the study, with feedback from members of an advisory committee consisting of representatives of the Government and child agencies, and an advisory committee consisting of children.

\section{The child advisory committee on researching foster care}

Following informal meetings with youth workers in a community centre sponsoring educational and recreational activities for socially excluded children, a general meeting took place with all children, during which we explained the purpose of the foster care study and asked them if they were willing to give us their advice on how to study foster care. The children decided that it was not possible for all of them to be involved, and chose to select representatives, 13 of whom were elected to speak for boys and girls from poor families, uprooted fostered children, war orphans, separated children living with extended families, and street and working children of various ages.

Over a four-month period we held meetings every two weeks, the first one centred on 'what research is', to continue with workshops on research questions, selection of participants, approaching children and giving feedback on findings. Techniques used included group discussions, listing, ranking, role-plays and debates. When we first explained our interest in understanding fostering, the advisors replied that many categories of children deserved to have their lives understood, and asked why we focused on fostered children only. This comment gave us the opportunity to explain the terms of reference for the study and our role vis-á-vis other stakeholders, namely the Government and Unicef. Communication about research boundaries proved fruitful, because it made children understand the sociopolitical context of the study and realise that they were contributing to a real project.The workshop in which we discussed research topics - 'What do we want to find out about fostering?' - gave us an indication of the children's main interests and concerns. The advisory members were mostly keen to know how foster children are treated and their position within the family; do they go to school, do they receive the same amount of food as the other children in the family, are they at ease, do foster parents treat them as their own?

During the workshop on selecting participants 'Who can give use the information we need?' - we were told that to obtain trustworthy information, it is not sufficient to talk to fostered children and parents, but it is better to contact other members of the community as they are likely to know more about the child than her/his foster parents. What the children were advising us to do was to adopt triangulation to cross-check information. They first listed, and then ranked in decreasing order of trust, those individuals who can give genuine information about the fostered child: the best friend(s) of the fostered child, foster parents, friends/classmates of the foster child, neighbours of the family, foster children themselves, workers in centres, teachers, authorities. They said that the most genuine information would come from the best friend, the confidant of the child rather than the children themselves, who may be afraid of exposing themselves. Following this meeting, we tried whenever possible to interview pairs of children who were best friends (having previously identified one of them as having been fostered), asking both the same general questions so as not to stigmatise the fostered child. The advisors also thought that speaking to neighbours before interviewing foster parents would help us to know things about the foster family that parents might not 
want to disclose, and that to obtain genuine information, any participant should be visited two or three times. The last two suggestions proved difficult to implement directly, but they made us more open to grasping informal comments and encouraged us to spend informal time in the field.

The workshop on procedures, 'How do we approach fostered children?', proved valuable in that advisors agreed that it was imperative to ask for the permission of parents before interviewing a foster child. This strong viewpoint was explained in connection with concerns for the well-being of the child herself/himself; granting permission was a way of making sure that the child would not be mistreated because she/he had participated in the study. Their genuine concern for the well-being of the fostered child highlighted a spontaneous grasp of ethical issues.

\section{Advice in interpreting findings}

As the research progressed, we used the workshops as an opportunity to ask advice on how to interpret ambiguous, unclear or unexpected findings. For instance, we had encountered cases of unaccompanied children who had not been told that they had been fostered (some of them had found out indirectly but pretended that they did not know, while others believed themselves to be natural children). We had also found out that some foster parents, given the negative connotation that the label 'orphan' carries in post-genocide Rwanda, considered the fact that the child did not know as a sign of success. It was difficult to strike a balance between the Convention right to an identity, the implications of the label 'orphan' and the parents' concerns about discrimination. We asked advisors for their opinion on our discrepant findings, and they replied that children should know that they are fostered for two reasons: to avoid the child finding out from an outsider, and to avoid problems on the death of parents, specifically concerning inheritance. The telling should be done sensitively, they suggested, possibly not even by the parents themselves but by a trusted adult who might take the child aside and explain the situation calmly.

The issue of inheritance often surfaced in the study, raised in group activities with children in schools and group discussions with foster parents, as a differentiating feature between formal and informal foster care and as a possible area of contention between fostered and natural siblings. We were aware that in the context of postgenocide Rwanda where many heads of households had been killed or their whereabouts were unknown, inheritance was a contentious issue, but we had not anticipated its widespread importance in the lives of foster families. When asked for their opinion on the issue, the advisors said that since parents had agreed to take in a child, inheritance should be distributed equally among foster and natural children, as well as both boys and girls. They also discussed the difficulty in apportioning land or properties, the most traditional form of inheritance, and suggested that foster parents should make all efforts to send fostered children to school as a form of portable inheritance.

Another ambiguous finding was whether or not the name of the fostered child should be put on the identity card of the foster parents. As fostering is supposed to be a short-term arrangement (different from adoption), would legalising it mean that it became de facto adoption? What would happen if natural parents traced the child and wanted him/her back? One such instance had been recorded in the course of our research. The advisors recommended that fostered children should be included on the identity cards of the parents as a form of protection for the fostered child.

The final meeting was about the structure and content of the foster care report. When they saw the table of contents, the children told us that the report should give greater emphasis to the future of fostered children what happens to them when they grow up - and contain a section with that title, which we accepted. When, at the end of the project, we thanked them for their assistance, one child replied that they were also thanking us because they had learned many things. 'I did not even know what research was before we began. We also thank you.' In the course of the workshops we learned the Rwandan proverb N'izibika zari amagi (Even the rooster once was an egg) that was used to remember the role that childhood plays in adulthood. We concluded the last workshop with a party to which all children were invited, having been reminded that the advisors had acted as representatives of all children and not as individuals, and therefore all should benefit. 


\section{Children outside parental care in institutions and community in Bangladesh}

The second study in which children acted as advisors was a research project on the conditions of children living outside parental care in Bangladesh.As the government of the People's Republic of Bangladesh, and local and national non-governmental organisations implemented policies and programmes within the framework of children's rights, it become apparent that certain groups of children were living in difficult circumstance. Urban dwellers, refugees, tribal groups and bedays (river gypsies) were particularly vulnerable to violence, sexual abuse and trafficking; disabled children, orphans, children of sex workers and children in institutions also experienced disadvantage and discrimination in their day-to-day lives (Government of Bangladesh \& Unicef, 2000).

Among the children living in difficulty were those living without one or both parents, whose parents were in prison or had separated, abandoned or missing children, and street working children, broadly referred as 'children living outside parental care'. These can be settled, migrant or uprooted children who are separated from their families. In 2001 the Bangladeshi Ministry of Social Welfare and Unicef commissioned a study to gain an overview of the conditions of these children, those living in institutions (orphanages) and communities, and to explore strategies for alternative care arrangements. The research sought to provide an insight into the views of children, their guardians, staff members and care leavers in three areas of the country: the urban capital Dhaka where rural-urban migration led many to live in slums, Mymensingh in rural Bangladesh where among others lived a community of stateless Bihari refugees, and Rangamati in the East of the country, where ethnic minorities including internally displaced persons resided. In each area, one government and one private institution and one community area were visited. Focus group discussions, semi-structured interviews and group activities (essay writing, social mapping and story creation) were conducted with boys and girls aged 4 to 18 living in institutions and the community, as well as interviews with guardians, service providers, key informants and leaders in institutions and communities. In total, 646 (82\%) children and 139 (18\%) adults participated in the research. Two advisory committees were formed to give feedback on the research process and output, one constituted of adults and one of children.

\section{The child advisory committee in researching children living outside parental care}

Adopting the experience of Rwanda as a model, we planned to set up a child advisory committee whose representatives would speak for children without a father, children without a mother, children without both parents, children living with a guardian and those living in institutions. But, as Chatty and colleagues (2005) also discovered, participation does not happen in a vacuum. In Bangladesh, a Muslim country, boys and girls do not normally reside in the same centres, nor are they used to interacting in mixed-gender workshops, which made us debate whether it was culturally sensitive to have a mixed advisory committee, better to have two separate ones, or realistic to have only one with either boys or girls. In the end, practicalities dictated the decision to collaborate with a non-governmental organisation whose beneficiaries were street and working girls living outside parental care, migrants themselves or children of ruralurban migrants. They were chosen because of an assumed familiarity with both life in the community and in an (open) institution. During a preliminary gathering, which took place late in the afternoon when the girls returned to the centre after a day working or studying outside, we introduced the purpose of the study and the role of the advisory committee. During the meeting, since most of the girls wanted to be involved in the committee, they all chose to attend the workshops rather than to select representatives. The participation of 20 to 35 girls meant that continuity became a challenge, and the depth and detail of feedback were less than in the foster care study, although we had revised our techniques to work with larger groups.

Given the difficulty of identifying children living outside parental care in Bangladesh, the first workshop was structured around terminologies and definitions. When asked 'Who do you think are those children who do not live with their parents?', the advisors listed street children, disadvantaged children, working children, those who live with a stepmother or stepfather, lost children and those whose parents had died, separated from the family because of poverty, abused by stepmother, lacking a 
guardian, parents making the wrong decision of sending them away, violence, trafficking, bad behaviour and family break-up. It is worth noting that most of the children listed are those most familiar to the girls, namely those whose situations resemble those of street and working children.

At the end of the meeting, the advisors came up with a definition of children outside parental care.

\section{A child who has lost both parents or the father or the mother, who is not cared for by anybody, who is without protection and assistance, and who is treated as an orphan.}

It is interesting to note that both children in the advisory committee and participants in the study offered a broader definition than the more standardised and narrowly outlined one we found in programmes and policy documents, which is based almost exclusively on socio-demographics characteristics rather than environmental vulnerability. For instance, according to the Muslim tradition, a child is considered to be 'orphan' if both parents or the father only (not the mother) die or abandon a child. This meant that many 'orphans' in institutions had mothers or relatives but were placed there due to poverty or to access services (education) otherwise unaffordable. One of the recommendations of the study was for the assessment of vulnerability to move beyond socio-demographic characteristics (death of parents) to include contextual vulnerability, so that poor children in slum areas, though not technically orphans but whose conditions resemble those of orphans, could also be entitled to social support.

When we examined possible research areas for investigation - 'what do we want to find out about these children?' - the advisors wished to know the specific life paths that led children to become separated: which types of children are living away from the family, what are the causes, how did they come to live on the street or to be living in an institution and, especially, who decided? They were keen to learn about their lives, problems and needs: what problems did/do they face in the family, what services are there for children in institutions, are the children in institutions happy, are there differences between life on the street and in orphanages, how are they growing up, what do they want to be in the future?
Advisors also listed and ranked those likely to give more trustworthy information in decreasing degree. In the community they were, in addition to the child, friends, teacher, neighbour, founder/owner of a centre, known persons and gentlemen (somebody with prestige in the community), and in institutions again friends, followed by staff (madams) and children themselves (equally in second position), teachers, guards and manager/bosses. To interview children, researchers need to go where they are, in institutions or on the streets, clubs, railway station, footpaths, verandas, brothels, slum, shelters and inside homes where they work as domestics. Again, it is worth noticing that the community places listed are those most familiar to street and working children.

On the basis of the feedback from the advisors, we revised the study to include additional questions, which was useful, and new categories of participants (friend of the child, neighbour and teacher), which proved only partly successful because of time limits. As we proceeded with the data collection and preliminary analyses, we returned to the centre to ask for feedback on ambiguous and unclear findings.

\section{Advisors' comments on the interpretation of findings}

Included among our planned visits to institutions were visits to baby homes, orphanages where very young children, probably orphans (both parents) or abandoned children, are looked after from birth to the age of five, without being visited by anybody or being able to leave the institution to visit family or relatives. At the age of five, they are transferred to mainstream institutions that cater for children who may have relatives or one parent alive, who receive monthly visits and occasionally leave the institution during holidays to stay with the mother or the extended family. We asked the advisors what recommendations should be put forward to support children without anybody.The advisors said that children who have lost both parents should be given more care and attention by their caregivers, teachers and classmates, that death should be explained to them gently (that everybody has to die and that some parents may be alive and others may be dead), and that those children living in institutions who still have their mother could invite children without parents to call their own mother 'mama'. 
During the research, we found that children were allowed to stay in institutions until the age of eighteen, but could leave earlier if they had a marriage proposal or a job prospect. Interviews with staff and young adults who had left the institution revealed difficulties in adjusting (rather than re-adjusting) to life in society after having spent most of the formative years in institutional care. When we discussed problematic transitions, advisors' overall recommendations were in the direction of bridging the gap between institutions and families. They recommended that staff in institutions give counsel and support to children so that they can learn to live in society, suggested development of links with those families who accept children, and thought that when children choose to go and live outside the institution, carers should visit and continue to give counsel and that both the child and the 'new' family should be open to making adjustments.

In the end, we managed four long sessions with the child advisory committee, due to constraints in both our and their schedules and methodological limitations in planning and implementation of the activity. They resulted in some practical and useful suggestions, and confirmed that children are interested in learning and commenting about children's lives. It also showed us that children know best about what they are familiar with, in this case street and working life rather than institutional life. Before proceeding with the general discussion, I will briefly compare and contrast the experience of involving children as advisors in the two research contexts.

\section{Comparing the involvement of children in advisory roles in Rwanda and Bangladesh}

It is commonly acknowledged that child participation is a valuable aspiration, but taking it for granted obscures the need to investigate when, how and where it works best or worst. In this section, I want to show that child participation in the research process is a methodological issue per se which is affected by the steps we take and the choices we make; diversities in the selection of advisors, procedures for planning and organising research methods workshops, and choice of techniques influence participation as a means and as an outcome. Above I showed how both studies shared the involvement of children as advisors and teaching of basic research methods to gain feedback, but the way in which the process unfolded resulted in different quality of information and relationships.

The selection of advisors proved crucial, in the same way as the selection of participants in any research project. While in Rwanda children were elected to represent care arrangements they were directly or indirectly familiar with, in Bangladesh street and working children were asked to advise on the lives of children living in institutions and community. We soon realised that children knew best about and were most interested in the lives of children in similar circumstances. This bias was evident in all aspects of the advisory process - informing selection of participants, questions to ask, feedback on ambiguous findings and discussion. It made us aware that involvement of children because they are children as distinct from adults is not only conceptually simplistic but also methodologically flawed, and that the closer the match between advisors and those children we want to understand, the richer the quality of feedback.

Second, while in the foster care study a small group of children were elected and were willing to commit their time to the process, in Bangladesh all the girls chose to attend the sessions, challenging the continuity of the training and diluting the efficacy of teaching research methods and the understanding of specific components. Group dynamics and familiarity with one another also differed between the contexts; children in Rwanda were more open because we met more regularly, in a smaller group and more frequently. This realisation led to a change in strategy in Bangladesh, where we replaced the training in research methods with consultative meetings, a compromise reached after assessing the time and resources that both facilitators and children were putting in. The second lesson we learned, similar to the observation made by Pain and Francis (2003), is that with transient groups continuity and development in time are a challenge; more regular meetings in small groups ensure continuity and allow for deeper discussions to surface and issues to be explored in greater detail.

A final methodological issue, not frequently examined, is the relationship and roles of researchers and children (Christensen, 2004), including their 
experience and expertise. The Rwandan facilitators, for instance, were not only experts in conducting research and facilitation but also knowledgeable about the social lives of Rwandan children. In Bangladesh, the strength of the researchers was their technical expertise; they knew how to conduct research on different topics, but did not have specific knowledge of children. These different skills affected the quality of the workshops themselves, knowledge of children proving as important as technical skills. Finally, my prior experience and knowledge of the two countries was also different. I had lived in Rwanda for four years before leading the foster care study, while I had never been in Bangladesh before the start of the project on children outside parental care, and my different positions affected my understanding of the socio-cultural realities of children and the quality of the training, which leads me to conclude with a statement in support of long-term anthropological work (Chatty et al, 2005; Christensen, 2004).

\section{Discussion}

Analysis of the involvement of children as advisors indicates that participation is best seen as part of the research strategy, described rather than simply cited in research documents. Even though the two examples are located in the 'South' and refer to children separated from their natural families for political and economic reasons, lessons learnt can be transferred and adapted to other contexts of migration and social exclusion in the 'North'. If Morrow and Richards (1996) suggest that respect for children's competencies 'needs to become a methodological technique in itself' (p100), here I have argued for the systematisation of a 'methodology of participation'.

\section{Methodological considerations}

Participation at different stages - choosing, setting up and leading the work of an advisory committee - follows the same principles and guidelines that inform any research study in the selection of participants (advisors), establishing relationships (for how long?, in what way?), choosing techniques (for small or large groups?) and analysing findings. When systematically planned, participatory research improves the reliability and validity of the research project (Thomas \& O'Kane, 1998) even though it is challenging and time-consuming (Chatty et al, 2005; Pain \& Francis, 2003).
Anderson (2000) writes that one of the dangers of research with children is that it can infantilise them, which can include talking down and restricting them to making only superficial responses, or involve inexperienced children rather than those with relevant experience who could give us much more informed responses. The comparison of the work of the two committees points to the value of selecting advisors according to their experience and knowledge, thus minimising the risk of infantilising them. Children with direct or indirect relevant experience are better placed to give more in-depth and complex information than those with less relevant knowledge. We also noticed that advisors' feedback was consistently made and justified having in mind the protection and well-being of the children participating in the studies, revealing the advisors' views on ethics and contributing to discussions on ethical issues in research with children (Morrow \& Richards, 1996; Thomas \& O'Kane, 1998; Wyness, 2006).

\section{'Varieties' of participation}

When carefully planned, the involvement of children as advisors is methodologically useful. However, one is still left with the question of whether, within the framework of discussion on participation in general, this activity can be considered participatory, and if so to what degree and in what way. Pain and Francis (2003) argue that extracting information or using participatory diagramming is not the same as empowering, and recommend that:

\section{the term 'participatory' should be avoided when the primary intention is traditional 'extractive' research for the purposes of gatbering information (p53),}

while Sinclair (2004) goes as far as to suggest that if participation is to be more meaningful to children and effective for social change, it is necessary for it to move beyond one-off or isolated instances of participation to become an integral part of our relationship with children. Taking a rather different view, Boyden and Ennew (1997) write that participation can mean either simply 'taking part' or being present, or 'knowing that one's actions are taken note of and may be acted on, sometimes called empowerment' (p33), while Thomas and O' Kane (1998) add an element of relativity when they claim that, though the involvement of youmg people in their project on 
children looked after by local authorities in England and Wales had began after the objectives and design of the study had been set,

\section{the conduct of the research was participatory in a stronger [my emphasis] sense than merely that it employed 'user-friendly' materials; children were involved not only in choosing how they participated personally but in consciously influencing the direction of the research and in making decisions about its dissemination (p341).}

Hart (1992)'s ladder of participation has become a classic tool to describe the manner in which relations between adult and children are managed in participatory projects.At the top of the ladder there are projects initiated by young people where decisions are shared with adults, and in the middle are activities that are adult-initiated and decisions shared with young people, those where children are consulted and informed or where they are assigned and informed. Tokenism, decoration and manipulation, situated at the bottom of the ladder, are viewed as nonparticipation. Despite criticisms of the ladder (Kirby \& Woodhead, 2003; Reddy \& Ratna, 2002), it offers a typology for thinking about children's involvement that moves beyond a binary idea of participation versus nonparticipation to include a hierarchical progression. More recently, Wyness (2006) has distinguished the involvement of children as 'meaning-maker' respondents from that of children as 'researchers' in adults' research projects where they can act as consultants or fieldworkers.

With the objective of contributing to these discussions on a methodology of participation, I suggest that we move beyond categorical oppositions or strictly hierarchical views to consider 'varieties' of participation and 'varieties' of social change. The involvement of children as advisors represents a specific type of participation that produced a specific kind of social change, within the life of the project. Children contributed to the decision-making process, and they had influence over the methods used, the questions asked, the interpretation of findings and the recommendations proposed. The fact that researchers went to them for advice meant that the relationship was different from that of researcher-participant. Teaching research methods using an example from real life was to some extent empowering, both in helping children understand their experience in relation to that of other children and in knowing that their feedback was included in the report to be disseminated to other stakeholders.

The participation of children as advisors resulted in an exchange of information and reciprocal learning which, as Landsdown (2002) writes, contributes to the range of benefits that children link with increased participation such as acquiring new skills, building self-esteem and contributing to making the world a better place.

Viewing power as inherent in research emphasises that research is a practice that is part of social life rather than an external contemplation of it, Christensen (2004) writes. We also found that the activities of the child advisory committee were positioned inside a web of negotiations involving the child advisory committee, the adult advisory committee, the consultants and the organisations that commissioned the study, making us all aware that 'participation is shaped and constrained by the social fabric' (Johnson \& Ivan-Smith, 1998 p5).

Finally, while conceptual discussions of childhood in general have adopted a new paradigm which views children as social actors, children in difficult circumstances tend to be characterised by internal and often oppositional attributes: vulnerable/resilient, victim/perpetrator, traumatised/healthy. If to respect children means not to:

\section{think in sharp dichotomies of wise adult/ immature child, infallible doctor/immature patient, but to see wisdom and uncertainty shared among people of varying ages and experiences (James, 2004 p158),}

then it is hoped that the comments made by the advisors will help us to move beyond such descriptions and to view children in difficult circumstances as social actors, active participants in the research process as they are in societal life.

\section{Acknowledgements}

Thanks are expressed to the organisations that facilitated the workshops, the Centre Presbyterian d'Amour pour 
les Enfants (CPAJ) in Rwanda and Aparajeyo in Bandgladesh, to the facilitators of the trainings, particularly to Charles Kalinganire in Rwanda and Tayeba Islam in Bangladesh, and most of all to the children who acted as advisors. Thanks also to Lila Pieters of Unicef and David Tolfree of Radda Barnen for insightful discussions on child participation.

\section{References}

Ackermann L, Feeny T, Hart J \& Newman J (2003) Understanding and evaluating children's participation: a review of contemporary literature. Unpublished report for Plan UK/Plan International.

Ahearn F, Loughbry M \& Ager A $(2003,1999)$ The experience of refugee children. In: A Ager (Ed) Refugees: Perspectives on the Experience of Forced Migration. London: Cassell.

Anderson P (2000) Children as researchers: the effects of participation rights on research methodology. In: P Christiansen \& A James (Eds) Research with Children: Perspectives and Practices. London and New York: Palmer Press.

Aries P (1962) Centuries of Childhood. New York:Vintage Books.

Barker J \& Weller S (2003) 'Is it fun?' Developing childrencentred research methods. International Journal of Sociology and Social Policy 23 (1/2) 33-58.

Bhabha J (2004) Seeking asylum alone: treatment of separated and trafficked children in need of refugee protection.

International Migration 42 (1) 141-8.

Boyden J (2001) Children's participation in the context of forced migration. Participatory Learning and Action 42 52-6.

Boyden J \& de Berry J (2004) (Eds) Children and Youth on the Front Line: Ethnography, Armed Conflict and

Displacement. Oxford: Berghahn Books.

Boyden J \& Ennew J (1997) Children in Focus: A Manual for Participatory Research with Children. Stockholm: Radda Barnen.

Chatty D, Crivello G \& Hundt GL (2005) Theoretical and methodological challenges of studying refugee children in the Middle East and North Africa: young Palestinians, Afghans and Sahrawi refugees. Journal of Refugee Studies 18 (4) 387-409.

Christensen P (2004) Children's participation in ethnographic research: issues of power and representation. Children and Society 18 165-76.

Christensen P \& Prout A (2002) Working with ethic symmetry in social research with children. Childbood 9 (4) 477-97.

Doná G \& Islam T (2003) Overview of the Conditions of Children outside Parental Care in Institutions and Communities. Dhaka: Unicef.

Doná G, Kalinganire C \& Muramutsa F (2002) The Rwandan Experience of Foster Care for Separated Children. Stockholm: Radda Barnen.
Eyber C \& Ager A (2004) Researching young people's experiences of war: participatory methods and the trauma discourse in Angola. In: J Boyden \& J de Berry (Eds) Children and Youth on the Front Line. Oxford: Berghahn.

Government of Bangladesh \& Unicef (2000) Situation Assessment and Analysis of Children and Women in Bangladesh. Dhaka: Unicef.

Grover S (2004) Why won't they listen to us? On giving power and voice to children participating in social research. Childhood 11 (1) 81-93.

Hart R (1992) Children's Participation: From Tokenism to Citizenship. Florence: Unicef.

Hek R (2005) The Experiences and Needs of Refugee and Asylum Seeking Children in the UK:A Literature Review. London: Department for Education and Skills, Research Report 635.

Hill M (2006) Children's voices on ways of having a voice: children's and young people's perspectives on methods used in research and consultation. Childhood 13 (1) 69-89.

Hurley J \& Underwood MK (2002) Children's understanding of their research rights before and after debriefing: informed assent, confidentiality and stopping participation. Child Development 73 (1) 132-43.

ICRC (2000) Do you Know this Child? Unaccompanied Children in Rwanda and the Great Lakes Region (19942000). Kigali: ICRC.

James A (2004) Understanding childhood from an interdisciplinary perspective: problems and potentials. In: PB Pufall \& RP Unsworth (Eds) Rethinking Childbood. London: Rutgers University Press.

Johnson V \& Ivan-Smith E (1998) Background to the issues. In: V Johnson, E Ivan-Smith, G Gordon, P Pridmore \& P Scott (Eds) Stepping Forward - Children and Young People's

Participation in the Development Process. London: Intermediate Technology Publications.

Kellet M (2005) Children as Active Researchers: A New Research Paradigm for the 21st Century? www.ncrm.ac.uk/publications/methodsreview/MethodsReview PaperNCRM-003.pdf - (accessed 12 June 2006).

Kellett M, Forrest R, Dent N \& Ward S (2004) 'Just teach us the skills please, we'll do the rest': empowering ten-year-olds as active researchers. Children and Society 18 329-43.

Kirby P \& Woodhead M (2003) Children's participation in society. In: H Montgomery, R Burr \& M Woodhead (Eds) Changing Childboods, Local and Global. Chichester: John Wiley and Sons Ltd.

Landsdown G (2002) Promoting Children Participation in Democratic Decision-Making. Innocenti Research Centre, Florence: UNICEF. 


\section{Children as Research Advisors: Contributions to a Methodology of \\ Participation' in Researching Children in Difficult Circumstances}

Machel G (2001) The Impact of War on Children. Toronto: University of British Columbia Press.

MacMullin CE \& Loughry M (2000) A child-centered approach to investigating refugee children's concerns. In: FL Ahearn Jr (Ed) Psychosocial Wellness of Refugees: Issues in Qualitative and Quantitative Research. New York: Berghahn Books.

Mahon A, Glendinning C, Clarke K \& Craig G (1996) Researching children: methods and ethics. Children and Society 10 145-54.

Mayall B (2002) Towards a Sociology of Childbood:Thinking from Children's Lives. Buckhingham: Open University Press.

Millar R \& Gallagher M (1996) The 'Things I Worry About' Scale: further developments in surveying the worries of postprimary school pupils. Educational and Psychological Measurement 56 972-94.

Minitraso, Unicef, Barakabaho, SCF-US (1996) Seminar Atelier sur la Promotion de Suivi a Base Communautaire des Enfants Vulnerables. Kigali: Ministraso.

Morrow V \& Richards M (1996) The ethics of social research with children: an overview. Children and Society 10 90-105.

Murray C (2005) Children and young people's participation and non-participation in research. Adoption and Fostering Journal 29 (1) 57-66.

Pain R \& Francis P (2003) Reflections on participatory research. Area 35 (1) 46-54.

Reddy N \& Ratna K (2002) (Eds) A Journey in Children's Participation. Bangalore India:The Concerned for Working Children. www.workingchild.org.
Simon A \& Ward LO (1974) Variables influencing the sources, frequency and intensity of worry in secondary school pupils. British Journal of Social and Clinical Psychology 13 391-6.

Sinclair R (2004) Participation in practice: making it meaningful, effective and sustainable. Children and Society 18 (2) 106-18.

Summerfield D (2000) Childhood, war, refugeehood and 'trauma': three core questions for mental health professionals. Transcultural Psychiatry 37 (3) 417-33.

Thomas N O'Kane C (1998) The ethics of participatory research with children. Children and Society 12 336-48.

Thomas S \& Byford S (2003) Research with unaccompanied children seeking asylum. British Medical Journal 327 (7428) 1400-2.

Tolfree D (1995) Roofs and Roots: The Care of Separated Children in the Developing World.Arena:Aldershot.

Veale A \& Doná G (2003) Street children and political violence: a socio-demographic analysis of street children in Rwanda. Child Abuse and Neglect The International Journal 27 (3) 253-69.

Williamson E, Goodenough T, Kent J \& Ashcroft R (2005) Conducting research with children: the limits of confidentiality and child protection protocols. Children and Society 19 (5) 397-409.

Wyness M (2006) Childhood and Society: An Introduction to the Sociology of Childbood. London: Palgrave. 